Tropical Journal of Pharmaceutical Research December 2020; 19 (12): 2631-2638

ISSN: $1596-5996$ (print); 1596-9827 (electronic)

(C) Pharmacotherapy Group, Faculty of Pharmacy, University of Benin, Benin City, 300001 Nigeria.

Available online at http://www.tjpr.org

Original Research Article

http://dx.doi.org/10.4314/tjpr.v19i12.22

\title{
Evaluation of the efficacy of ethanol leaf extract of Helichrysum petiolare Hilliard and B.L. Burtt against skin aging
}

\author{
Idowu Jonas Sagbo*, Wilfred Otang-Mbeng \\ School of Biology and Environmental Sciences, University of Mpumalanga, Private Bag X11283, Mbombela 1200, South Africa
}

*For correspondence: Email: Jonas.sagbo@ump.ac.za; Tel: +27621320933

Sent for review: 11 May 2020

Revised accepted: 16 November 2020

\begin{abstract}
Purpose: To determine the efficacy of Helichrysum petiolare ethanol leaf extract against skin aging. Methods: The cytotoxic potential of the plant extract towards human dermal fibroblast (MRHF) cells was determined by Hoechst 33342/Propidium iodide (PI) staining. Effect of $\mathrm{H}$. petiolare extract on reactive oxygen species (ROS) levels in MRHF cells and NO (nitric oxide) production in RAW 246.7 cells activated by LPS (lipopolysaccharides) was investigated. The inhibitory effect of the extract against collagenase, elastase, tyrosinase and protein glycation was also evaluated.

Results: The extract did not display cytotoxicity towards MRHF cells at the tested concentrations when compared to the trend seen with the untreated control $(p<0.05)$. The extract caused a significant decrease $(p<0.05)$ in ROS levels in MRHF cells in a concentration-dependent manner and also demonstrated a reduction in NO production in RAW cells with no toxicity. Furthermore, the extract produced a weak inhibition of collagenase, elastase and tyrosinase activities when compared to the corresponding positive controls, but effectively inhibited protein glycation at the tested concentrations. Conclusion: The findings suggest that the ethanol leaf extract from $\mathrm{H}$. petiolare has the potential to mitigate skin aging and therefore needs to be further investigated for possible clinical applications.
\end{abstract}

Keywords: Cytotoxicity, Efficacy, Helichrysum petiolare, MRHF cells, Oxidative stress, Protein glycation; skin aging

\begin{abstract}
This is an Open Access article that uses a fund-ing model which does not charge readers or their institutions for access and distributed under the terms of the Creative Commons Attribution License (http://creativecommons.org/licenses/by/4.0) and the Budapest Open Access Initiative (http://www.budapestopenaccessinitiative.org/read), which permit unrestricted use, distribution, and
\end{abstract} reproduction in any medium, provided the original work is properly credited.

Tropical Journal of Pharmaceutical Research is indexed by Science Citation Index (SciSearch), Scopus, International Pharmaceutical Abstract, Chemical Abstracts, Embase, Index Copernicus, EBSCO, African Index Medicus, JournalSeek, Journal Citation Reports/Science Edition, Directory of Open Access Journals (DOAJ), African Journal Online, Bioline International, Open-J-Gate and Pharmacy Abstracts

\section{INTRODUCTION}

Skin diseases have recently been of major health challenges worldwide and they amount to about $34 \%$ of all occupational diseases encountered [1]. They are frequently occurring health challenges affecting people of all ages and they are accountable for the existing trend of increased morbidity and untimely death [2]. Skin disease including aging, rash, wrinkles, rosacea, vitiligo and scabies have been reported to occur in many human populations and constitute one of the major reasons for medical consultation [2]. Report has indicated that there have been several drugs available for managing skin disorders, these drugs have been found to be harmful to human health as they exhibit several side effects like glaucoma, eyelid edema, conjunctival hyperemia, skin dryness, irritation 
and allergic reaction [3]. It has also been reported that prolonged use of tetracycline, an antibiotic used to treat many skin conditions, induces side effects in eye organs. [3].

Methotrexate, a drug used to treat psoriasis, by reducing the production of the skin cells and suppressing inflammation. It has been frequently reported to cause numerous side effects, including severe liver damage and upset stomach [4]. Cyclosporine, a drug similar to methotrexate in effectiveness, is reported to increases the risk of infection and other health complications, including kidney problems [5]. Based on these adverse effects of these synthetic drugs, there is increased demand for new drugs with fewer or no side effects. Thus, it is imperative to explore alternative medicine most especially herbal remedies to discover new drugs for the treatment of skin aging and other skin related diseases.

Helichrysum petiolare Hilliard and B.L. Burtt (Asteraceae) is one of the well-known and the most frequently used members of Helichrysum genus. It is a vigorous shrub that grows to a height of $6 \mathrm{~cm}$. The plant is found in the drier inland parts along forest margins of the Western Cape, KwaZulu-Natal and Eastern Cape. The leaves of the plant are used for various medicinal purposes, including treatment of skin diseases, asthma and chest problems $[6,7]$. Also, the leaf juice of the plant is extensively used to prevent infections [7]. Reported pharmacological studies of $H$. petiolare extracts revealed antiinflammatory, antimicrobial and antioxidant properties [8]. Other reports have also found that extracts of $H$. petiolare are toxic towards Graham cells [9]. Previously reported phytochemical compounds, include phytol and eucalyptol, flavonoids, phloroglucinol, spathulenol, pyrenes, camphorene, caryophyllene oxide $[8,10]$.

The $H$. petiolare was chosen for this study due to its broad traditional usage for the treatment of skin diseases. The present study was therefore undertaken to determine the efficacy of $H$. petiolare ethanol extract against skin aging.

\section{EXPERIMENTAL}

\section{Reagents}

Human dermal fibroblast (MRHF) and RAW 264.7 (mouse macrophages) cells were acquired from Celonex (Johannesburg, South Africa). RPMI (Roswell Park Memorial Institute Medium) 1640, FBS (Fetal bovine serum) and FCS (Fetal calf serum) were purchased from Biowest (Logan, UT, USA). DPBS (Dulbecco's phosphate-buffered saline) with/without $\mathrm{Ca}^{2+}$ and $\mathrm{Mg}^{2+}$, DMEM (Dulbecco's modified Eagle's medium) and Trypsin-EDTA were acquired from HyClone, Longa, UT, USA. The Bis Benzamide H 33342 trihydrochloride (Hoechst 33342) and Annexin V-FITC/Propidium lodide kit were obtained from MACS Miltenyi Biotec, Cologne, Germany. The CellRox ${ }^{\circledR}$ Orange reagent was obtained from Molecular Probes $®$-Life Technologies-Thermo Fisher Scientific, (Logan, UT, USA). The other reagents used were all acquired from Sigma-Aldrich, St. Louis, MI, USA.

\section{Plant material}

Helichrysum petiolare leaves were collected from the Eastern Cape, South Africa. The plant was identified by a botanist (Prof. Chris Cupido) at the University of Fort Hare's Giffen Herbarium, where a voucher specimen (no. HEL-1340) was deposited. The ethanol extract of $H$. petiolare was prepared by pulverizing approximately $60 \mathrm{~g}$ of the dried leaves and then extracting the resulting powder with ethanol $(1000 \mathrm{~mL})$. The extract was then filtered and the filtrate was concentrated using a rotary evaporator (Heidolph Schwabach, Germany). Thereafter, the dried extract was stored at $-20{ }^{\circ} \mathrm{C}$ before use.

\section{Maintenance of cell cultures}

Cells (MRHF and RAW 264.7 cells) were grown in separate culture dishes in DMEM medium added with fetal calf serum (10\%) and incubated in a $5 \% \mathrm{CO}_{2}$ incubator.

\section{Imaging and analysis for cell-based assays}

The ImageXpress Micro XLS Widefield HighContent Analysis System (Molecular Devices ${ }^{\circledR}$, San Jose, CA, USA) was used to image cells

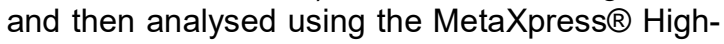
Content Image Acquisition \& Analysis Software (Molecular Devices $₫$, San Jose, CA, USA) for some cell-based experiments performed in this study.

\section{Cytotoxicity assay}

The cells (MRHF) were seeded at a density of 8000 cell/well using $100 \mu \mathrm{L}$ aliquots and left to attach overnight. The cells were treated with plant extract $(25-100 \mu \mathrm{g} / \mathrm{mL})$ and then incubated for $24 \mathrm{~h}$ at $37{ }^{\circ} \mathrm{C}$ in a $5 \% \mathrm{CO}_{2}$ incubator. After the incubation period, the treatment medium was removed and replaced with $50 \mu \mathrm{L}$ of staining solution $(5 \mathrm{~mL}$ binding buffer (phosphate buffer saline with $\mathrm{Ca}^{2+}$ and $\left.\mathrm{Mg}^{2+}\right)$ containing Annexin V-FITC reagent $(50 \mu \mathrm{L})$ and $2 \mu \mathrm{L}$ Hoechst 33342 solution $(10 \mathrm{mg} / \mathrm{mL}))$. 
After $15 \mathrm{~min}$ of incubation, $50 \mu \mathrm{L}$ of propidium iodide $(2 \mu \mathrm{g} / \mathrm{mL})$ was added and then incubated for $5 \mathrm{~min}$. Images were acquired and analyzed.

\section{Oxidative stress assay}

The oxidative stress assay was performed as described previously [11]. Cells (MRHF) were seeded in a 96-wells plate at a density of 8000 cells/ well and then left to attach overnight. Treatment of the cells was initiated by adding varying concentrations $(50-200 \mu \mathrm{g} / \mathrm{mL}$ ) of the plant extract or $\mathrm{N}$-acetylcysteine $(5 \mathrm{mM})$. After 24 $\mathrm{h}$ of incubation, tert-butyl hydroperoxide (100 $\mu \mathrm{M})$ was added to the cells to induce oxidative stress and then incubated at $37^{\circ} \mathrm{C}$ for an additional $2 \mathrm{~h}$. Then, the spent culture medium was removed and replaced by adding $50 \mu \mathrm{L}$ staining solution (PBS $(10 \mathrm{~mL})$ containing CellRox orange stock $(20 \mu \mathrm{L})$ and Hoechst $33342(2 \mu \mathrm{L})$ solution) and incubated for $30 \mathrm{~min}$ at $37^{\circ} \mathrm{C}$. Then the images were acquired and analyzed.

Inhibition of NO (nitric oxide production) in RAW 264.7 (mouse macrophage) cells

The assay was performed as described previously [12]. The cells (RAW 264.7) were seeded at a density of $1 \times 10^{5}$ cells per well and allowed to attach. The spent medium was aspirated and then replaced with medium containing plant extract $(6.25-100 \mu \mathrm{g} / \mathrm{mL})$ or positive control, aminoguanidine (100 $\mu \mathrm{M})$. Thereafter, $1 \mu \mathrm{g} / \mathrm{mL}$ of LPS (lipopolysaccharides) was pipetted to each well and then incubated at $37^{\circ} \mathrm{C}$. After $18 \mathrm{~h}$ of incubation period, $50 \mu \mathrm{L}$ of the medium was removed by aspiration and then transferred into a new 96-well plate. Then, $50 \mu \mathrm{L}$ of Griess reagents (prepared as 1:1 ratio, v/v of 1 $\%$ sulfanilamide and $0.1 \%$ naphthylethylenediamine dihydrochloride in $5 \%$ phosphoric acid) was added and then incubated for an additional $10 \mathrm{~min}$, after which the absorbance was measured at $540 \mathrm{~nm}$. To assess the cell viability, $100 \mu \mathrm{L}$ culture medium containing 0.5 $\mathrm{mg} / \mathrm{mL}$ MTT (3-(4,5-dimethylthiazol-2-yl)-2,5diphenyltetrazolium bromide) was added to the remaining cells and then incubated at $37^{\circ} \mathrm{C}$ for 1 $\mathrm{h}$ after which the spent medium was removed and replaced with DMSO $(100 \mu \mathrm{L})$. Then, the absorbance was measured at $540 \mathrm{~nm}$.

\section{Collagenase inhibition assay}

The collagenase assay was carried out as described previously [12]. The reaction mixture contained $10 \mu \mathrm{L}$ extract $(50-200 \mu \mathrm{g} / \mathrm{mL})$ or EDTA $(0.5 \mathrm{mM})$ or catechin $(0.5 \mathrm{mM}), 10 \mu \mathrm{L}$ collagenase enzyme solution and $10 \mu \mathrm{L}$ gelatin
(2 $\mathrm{mg} / \mathrm{mL}$ ). The resulting mixture was then incubated at $37{ }^{\circ} \mathrm{C}$. After $1 \mathrm{~h}$ incubation, $20 \mu \mathrm{L}$ CBB (Coomassie Brilliant Blue) was added and shaken for an additional $5 \mathrm{~min}$ and then centrifuged at 500 rcf (relative centrifugal force). The supernatant was removed after which $50 \mu \mathrm{L}$ washing solution (prepared as $40 \%$ methanol and $10 \%$ acetic acid) was then added to wash each well and then discarded. Thereafter, the remaining pellet in the wells was solubilised by adding $50 \mu \mathrm{L}$ DMSO and the absorbance was measured at $600 \mathrm{~nm}$.

\section{Elastase inhibition assay}

The elastase assay was performed based on the method previously described by Thring et al. [13] with some modifications. The reaction mixture contained $25 \mu \mathrm{L}$ extract $(25-200 \mu \mathrm{g} / \mathrm{mL})$ or Silymarin $(100 \mu \mathrm{M}), 100 \mathrm{mM}$ Tris- $\mathrm{HCl}(\mathrm{pH} 8.0)$ and $10 \mu \mathrm{L}$ porcine pancreatic elastase. The resulting mixture was incubated for $5 \mathrm{~min}$ at $37^{\circ} \mathrm{C}$. After the incubation period, $20 \mu \mathrm{L}$ substrate solution (4.4 mM succinyl-Ala-Ala-Alap-nitroanilide in Tris- $\mathrm{HCl}$ buffer) was added to the mixture to start the reaction and the absorbance was read at $410 \mathrm{~nm}$ for $10 \mathrm{~min}$ at $1 \mathrm{~min}$ intervals.

\section{Tyrosinase inhibition assay}

Tyrosinase assay was performed based on the method previously described by Otang-Mbeng and Sagbo [14]. The reaction mixture contained $20 \mu \mathrm{L}$ extract (25- $200 \mu \mathrm{g} / \mathrm{mL}$ ) or Kojic acid and blank (phosphate- buffered saline, $\mathrm{pH}$ 6.8) were pipetted into the 96-well plate. Then, an enzyme solution $(20 \mu \mathrm{L})$ and buffer $(10 \mu \mathrm{L})$ were added, while for the control wells only $30 \mu \mathrm{L}$ buffer was added. Then, $50 \mu \mathrm{L}$ L-DOPA $(4 \mathrm{mM})$ solution (substrate) was added to the resulting mixture to initiate the reaction. Thereafter, the absorbance was read at $475 \mathrm{~nm}$ for $6 \mathrm{~min}$ at $1 \mathrm{~min}$ intervals.

\section{Protein glycation assay}

The reaction mixture contained the test sample (25 - $200 \mu \mathrm{g} / \mathrm{mL}$ ) or aminoguanidine $(20 \mathrm{mM})$, glucose solution $(500 \mu \mathrm{L})$ and $500 \mu \mathrm{L}$ gelatin substrate. The resulting mixture was then incubated at $55^{\circ} \mathrm{C}$ for $24 \mathrm{~h}$. Thereafter, $200 \mu \mathrm{L}$ of the mixture was removed by aspiration and then transferred to a new black 96-well plate. The fluorescent intensity was then measured at 370 $\mathrm{nm}$ (excitation) and $440 \mathrm{~nm}$ (emission).

\section{Statistical analysis}

Statistical analysis was accomplished using the Student's $t$-test (two-tailed). Three replicate values for each test sample (ethanol extract) 
were compared with replicate values for the controls.

\section{RESULTS}

\section{Cytotoxicity}

The cytotoxic result obtained from the Hoechst/PI dual staining method revealed that $H$. petiolare extract was not toxic to MRHF cells at all the tested concentrations, as evidenced by the trend seen in the percentage of the live cells (Figure 1). However, a minor increase in the number of apoptotic cells was seen across the tested concentrations. This was further supported by the percentage of relative cell count (\% RCC). Treatment of the cells with positive control, melphalan caused a significant decrease in the number of live cells when compared to that of extract and untreated control.

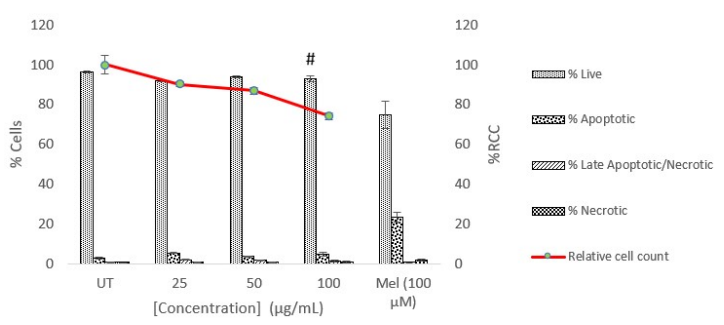

Figure 1: Cytotoxicity of $H$. petiolare on MRHF cells using Hoechst/PI staining. Data are expressed as mean $\pm \mathrm{SD}, \mathrm{n}=3$; \#p<0.05, compared to untreated (UT) control. Mel: melphalan

\section{Oxidative stress}

The result (Figure 2) revealed that the increasing concentrations $(50-200 \mu \mathrm{g} / \mathrm{mL})$ of the extract caused a significant reduction in TBHP-induced ROS levels in MRHF cells. Also, at the maximum concentration $(200 \mu \mathrm{g} / \mathrm{mL})$ tested, the extract reduced ROS levels in the cells and this reduction was greater than the trend seen in the untreated cells and $\mathrm{N}$-acetylcysteine (positive control), a well-known inhibitor of ROS.

\section{Inhibition of NO (nitric oxide production) in RAW 264.7 cells}

Treatment with the extract $(6.25-100 \mu \mathrm{g} / \mathrm{mL})$ achieved a significant decrease of NO production in RAW cells in a concentration-dependent manner. At the high concentrations (50 and 100 $\mu \mathrm{g} / \mathrm{mL}$ ), the extract reduced $\mathrm{NO}$ production in RAW cells than that of the untreated control and aminoguanidine (positive controls). As described in Figure 3 , the number of viable activated RAW 264.7 cells was not affected by the extract. This implies that the reduction of the NO production in RAW cells was not as a result of cell death.

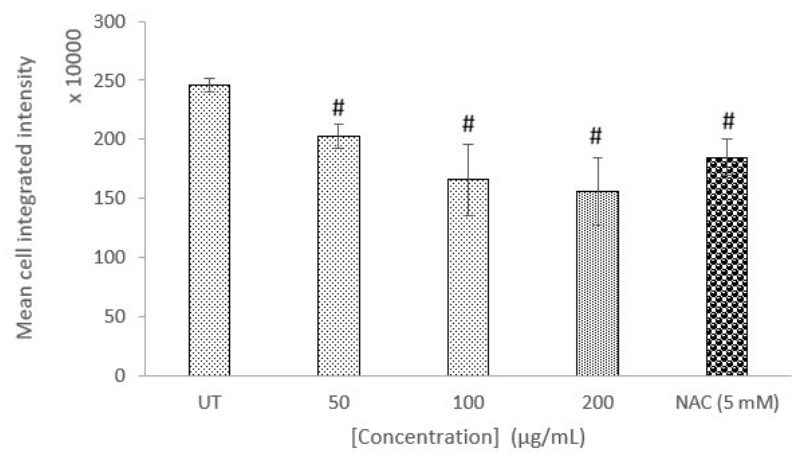

Figure 2: TBHP-induced ROS levels in MRHF cells treated with ethanol extract of $H$. petiolare. Data are expressed as mean $\pm \mathrm{SD}, \mathrm{n}=3$; \#p<0.05, compared to untreated (UT) control. NAC: N-acetylcysteine
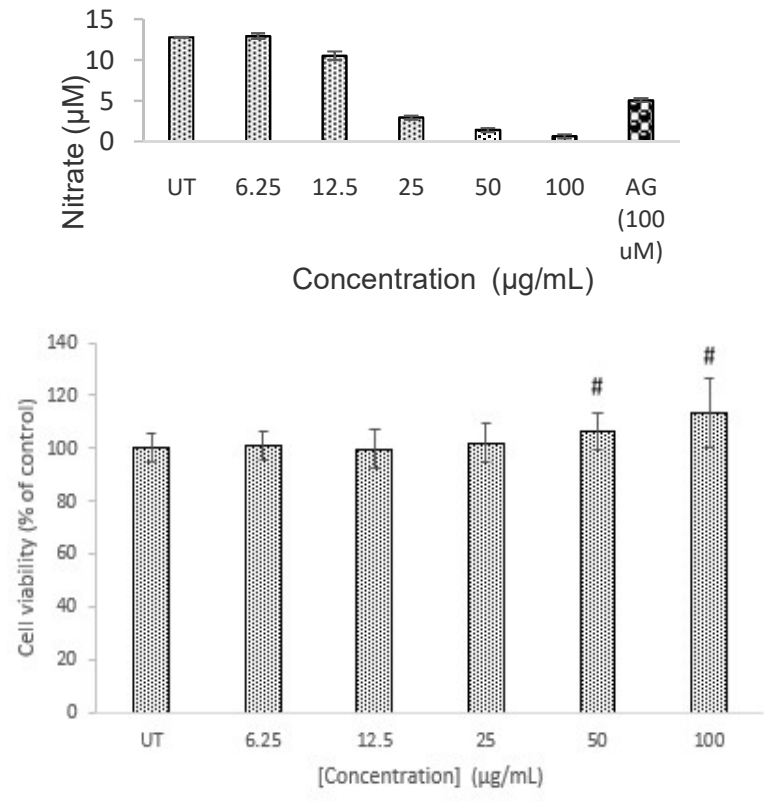

Figure 3: NO production in LPS activated RAW 264.7 cells treated with various concentrations of $H$. petiolare extract. The corresponding cell viability as determined by MTT assay was also shown. Aminoguanidine (AG) was used as a positive control for the inhibition of NO production in response to LPS activation. Data are expressed as mean $\pm \mathrm{SD}, \mathrm{n}=3$; \#p<0.05, compared to untreated (UT) control

\section{Collagenase inhibition assay}

The extract was tested for the inhibitory effect on collagenase activity. Catechin and EDTA were used as positive controls. The extract exhibited no inhibition of collagenase activity at all the tested concentrations (Figure 4). A weak inhibition (less than $10 \%$ ) was observed at the highest concentration $(200 \mu \mathrm{g} / \mathrm{mL})$ tested when 
compared to the untreated control (0 \%). However, the positive controls, catechin and EDTA, inhibited the collagenase enzyme by 46 and $50 \%$ respectively.

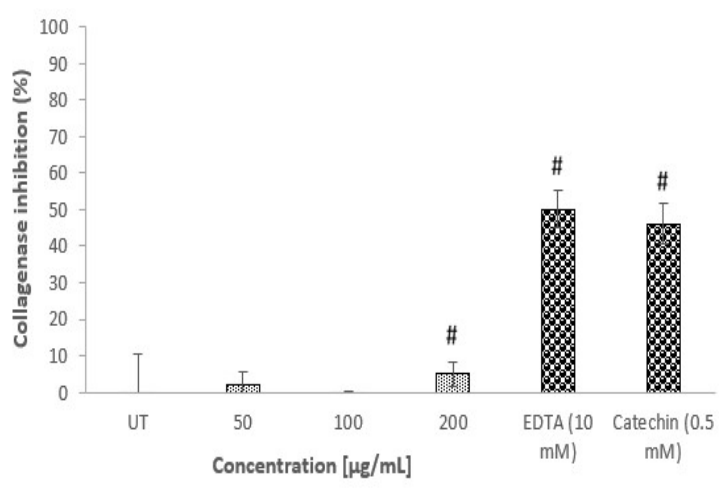

Figure 4: Collagenase inhibition effect of ethanol extract from $H$. petiolare. Data are expressed as mean $\pm \mathrm{SD}, \mathrm{n}=3 ; \# p<0.05$, compared to untreated (UT) control

\section{Elastase inhibition assay}

As described in Figure $5, H$. petiolare extract demonstrated a weak effect of elastase activity at the tested concentrations $(25-200 \mu \mathrm{g} / \mathrm{mL})$, this effect was stronger than that of the untreated control, but lower as compared to the positive control, silymarin (50.6\%), a well-known inhibitor of elastase activity.

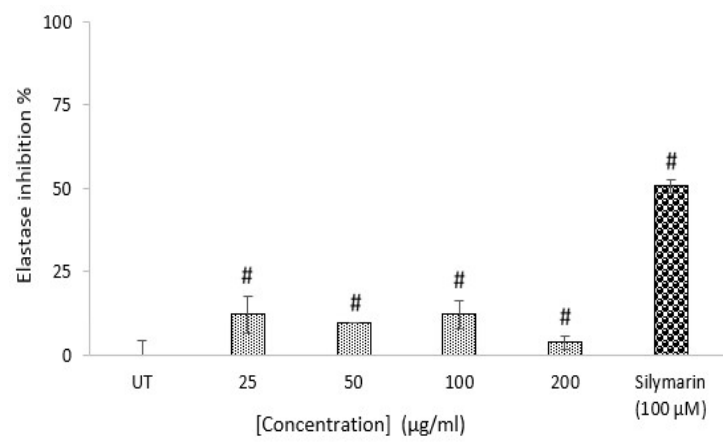

Figure 5: Elastase inhibition effect of ethanol extract from $H$. petiolare. Data are expressed as mean $\pm S D$, $\mathrm{n}=3 ; \# p<0.05$, compared to untreated (UT) control

\section{Tyrosinase inhibition}

The plant extract caused a weak inhibition (< $5 \%$ ) of tyrosinase activity at all the tested concentrations, although the inhibitory effect of the extract was different from that of the untreated control (Figure 6). However, Kojic acid, used as positive control showed a strong inhibition $(80 \%)$ of the enzyme.

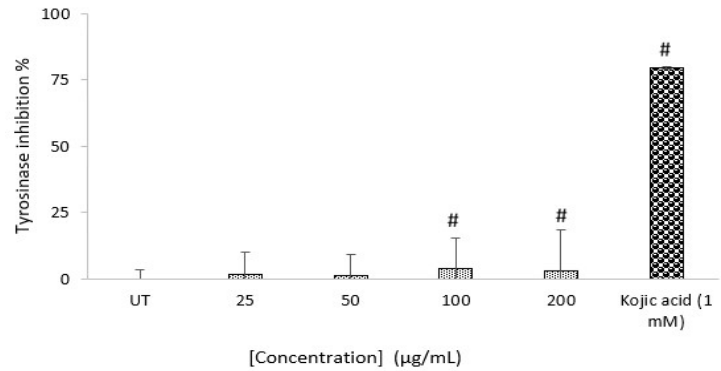

Figure 6: Tyrosinase inhibitory effect of ethanol extract from $H$. petiolare. Data are expressed as mean $\pm \mathrm{SD}, \mathrm{n}=3 ; \# p<0.05$ compared to untreated (UT) control

\section{Protein glycation}

Figure 7 shows the result of the effect of the extract on protein glycation. The extract displayed a moderate dose-dependent inhibition. At the tested concentrations $(25-200 \mu \mathrm{g} / \mathrm{mL})$, the extract showed better effects than that of the untreated control. It was also revealed that the positive control, aminoguanidine exhibited maximum inhibitory effects $(76 \%)$ on protein glycation.

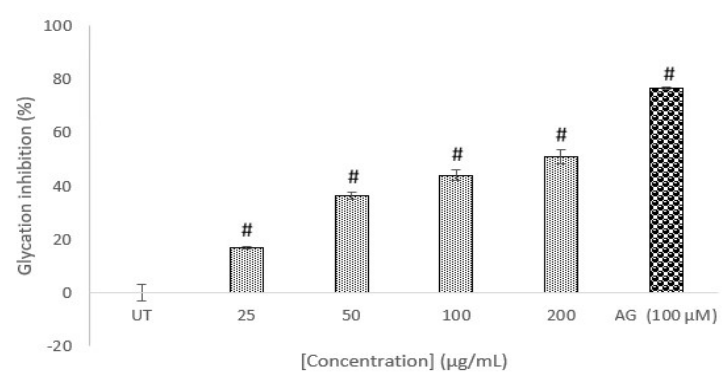

Figure 7: Protein glycation inhibition effect of ethanol extract from $H$. petiolare. Data are expressed as mean $\pm \mathrm{SD}, \mathrm{n}=3$; $\# p<0.05$, compared to untreated (UT) control. AG: aminoguanidine

\section{DISCUSSION}

The cytotoxicity studies performed with MRHF cells revealed that the extract was not toxic to the cells at the tested concentrations. This supports the claim that $H$. petiolare extract could be used without the anxiety of toxicity. However, it should be noted that the scope of this claim is limited to the highest concentration of the extract tested $(100 \mu \mathrm{g} / \mathrm{mL})$ and the MRHF cell line used in this study. Therefore, future studies using in vivo studies are recommended.

Oxidative stress plays an important role in the pathogenesis of dermatological conditions [15]. Studies have also shown that continuous exposure to environmental factors leads to 
modifications in the connective tissue due to the formation of ROS, as well as enzyme action, which results in frequent skin ailments [16]. The results obtained for TBHP-induced ROS levels in MRHF cells when treated with plant extract indicated a significant dose-dependent decrease in ROS levels. This reduction of ROS level in MRHF cells could be attributed to the presence of phytochemicals in the $H$. petiolare extract [10]. This is the first scientific report of the effect of $H$. petiolare in TBHP-induced ROS levels in MRHF cells. Report has indicated that over-production of NO (nitric oxide) promotes inflammation [17]. In this study, the extract inhibited NO production with no significant toxicity towards activated RAW 264.7 cells at the concentration tested. This inhibition of NO production in RAW cells may be due to the ability of the extract to suppress the expression of nitric oxide synthase (iNOS) thereby reducing nitric oxide formation. It has been indicated that secondary metabolites play a pivotal role in suppressing inflammatory initiators [18]. Therefore, the anti-inflammatory ability displayed by the ethanol extract of $H$. petiolare can be partly attributed to the presence of bioactive compounds earlier reported in the $H$. petiolare extract [10].

Collagen and elastin play a significant role in creating skin strength, firmness, and shape. In normal skin, collagen and elastin are formed and decomposed repeatedly to maintain the dermal structure. Ultraviolet (UV) irradiation exposure causes a decline in collagen and elastin fibers in the connective tissue of the skin. These fibers are besmirched by matrix metalloproteinases (MMPs) or serine proteinase (collagenase and elastase). Therefore, the regulation of these enzymes is very essential for maintaining skin health. The results obtained indicated that $H$. petiolare extract exhibited weak inhibition of collagenase and elastase activities at all the tested concentrations. However, report has shown that the collagenase enzyme contributes positively to wound healing by removing debris and preventing scar tissue formation due to excess collagen formation [19]. Research has also revealed that collagenase heals burn wounds and it has been recommended for the treatment of burns [20]. Therefore, the weak effect of the extract on collagenase enzyme may be recognized as being advantageous.

Over-activity of tyrosinase leads to overproduction of melanin, and abnormal production of melanin pigment is accountable for several skin diseases, including senile lentigo and melisma [21]. In this study, the effect of the extract on the catalytic activity of tyrosinase was investigated. The extract displayed a weak effect of tyrosinase enzyme at all the tested concentrations. This observation is in agreement with the results obtained from Sonka [22] who reported weak inhibition of tyrosinase when tested with methanol extract of $H$. petiolare at the concentration of $50 \mu \mathrm{g} / \mathrm{mL}$. It could be deduced from this study that $H$. petiolare may not be considered a potential candidate in alleviating abnormal melanin production.

Protein glycation is one of the many natural aging processes that occur in the skin. It causes undesired cross-linking of collagen and elastin fibers. As a consequence, the elasticity of the extracellular matrix (ECM) is altered, affecting mainly vascular functions. Studies have also revealed that altering the balance between synthesis and degradation of ECM as a result of glycated modification may accelerate skin aging and upsurge skin stiffness [23]. Therefore, it is important to screen for inhibitors of the glycation process. The extract showed a moderate concentration-dependent inhibition of protein glycation with the maximum inhibition observed at the highest tested concentration $(200 \mu \mathrm{g} / \mathrm{mL})$. Although, the precise mode of action by which this plant extract exhibits its antiglycation activity has not been proven. Previous study has indicated that antiglycation agents may act by suppressing the formation of advanced glycation end products (AGEs) by inhibiting more oxidation of Amadori product and metal-catalysed glucose oxidation [24]. Therefore, it could be inferred from this study that the inhibitory effects observed could be ascribed to the inhibiting ability of the $H$. petiolare extract thereby delaying the formation of AGEs.

\section{CONCLUSION}

$H$. petiolare extract produces a significant decrease in ROS levels in MRHF cells as well as a significant decrease in NO production in RAW 264.7 cells. The extract also demonstrates a strong potential against protein glycation, indicating its potential for preventing skin aging and an increase in skin stiffness. Furthermore, the extract did not show any significant cytotoxicity towards MRHF cells. The absence of cytotoxicity supports the safe and efficient use of this plant.

\section{DECLARATIONS}

\section{Acknowledgement}

The research was funded by the National Research Foundation (NRF), South Africa (Grant no: 105161). 


\section{Conflict of interest}

No conflict of interest is associated with this work.

\section{Contribution of authors}

We declare that this work was done by the authors named in this article and all liabilities pertaining to claims relating to the content of this article will be borne by the authors. Idowu Jonas Sagbo and Wilfred Otang-Mbeng designed all the experiments and revised the paper. Idowu Jonas Sagbo wrote the paper. Idowu Jonas Sagbo and Wilfred Otang-Mbeng final approve.

\section{Open Access}

This is an Open Access article that uses a funding model which does not charge readers or their institutions for access and distributed under the terms of the Creative Commons Attribution License (http://creativecommons.org/licenses/by/ 4.0) and the Budapest Open Access Initiative (http://www.budapestopenaccessinitiative.org/rea d), which permit unrestricted use, distribution, and reproduction in any medium, provided the original work is properly credited.

\section{REFERENCES}

1. Abbasi AM, Khan MA, Ahmad M, Zafar M, Jahan $S$, Sultana S. Ethnopharmacological application of medicinal plants to cure skin diseases and in folk cosmetics among the tribal communities of North-West Frontier Province, Pakistan. J Ethnopharmacol 2010; 128: 322-335.

2. Njoronge GN, Bussmann R. Ethnotherapeutic management of skin diseases among the Kikuyus of Central Kenya. J Ethnopharmacol 2007; 111: 303-307.

3. Nguyen T, Zuniga R. Skin conditions: new drugs for managing skin disorders. FP Essent 2013; 407(4): 1116.

4. Czarnecka-Operac $M$, Sadowska-Przytocka A. The possibilities and principles of methotrexate treatment of psoriasis - the updated knowledge. Postep Derm Alergo 2014; 6: 392-394.

5. Singh K, Argáe C. Cyclosporine for moderate-severe plaque psoriasis in adults: a review of clinical effectiveness and safety. Ottawa (ON). CADTH 2018; 4.

6. Hutchings $A$, Scott AH, Lewis G, Cunningham A. Zulu Medicinal Plants. Univ Natal Press Pietermaritzbg 1996

7. Josia M. Medicinal properties of some plants used for the treatment of skin disorders in the OR Tambo and Amathole municipalities of the Eastern cape province. Masters Dissertation Dep Bot Walter Sisulu University; 2013.
8. Lourens ACU, Reddy D, Baser KHC, Viljoen AM, Van Vuuren S. In vitro biological activity and essential oil composition of four indigenous South African Helichrysum species. J Ethnopharmacol 2004; 95: 253258.

9. Lourens ACU, Van Vuuren SF, Viljoen AM, Davids $H$, Van Heerden FR. Antimicrobial activity and in vitro cytotoxicity of selected South African Helichrysum species. South African J Bot 2011; 77: 229-235.

10. Otang-mbeng W, Sagbo IJ. Gas Chromatography - Mass Spectrometry Analysis of the Volatile Compounds from the Ethanol Extracts of Bulbine asphodeloides and Helichrysum petiolare. Pharmacogn Rev 2019; 11(3): 219-223.

11. Sagbo IJ, Mbeng WO. Chemical Constituents, Antioxidative, Cytotoxic and Genotoxic Effects of Miscanthus Capensis Roots Extract. Asian J Pharm Clin Res 2019; 12(12): 277-232.

12. Sagbo IJ, van der Venter M, Koekemoer T, Bradley G. In Vitro Antidiabetic Activity and Mechanism of Action of Brachylaena elliptica (Thunb.) DC. Evid Based Complement Altern Med 2018; 2018.

13. Thring TSA, Hili $P$, Naughton DP. Anti-collagenase, antielastase and anti-oxidant activities of extracts from 21 plants. BMC Complement Altern Med 2009; 9: 27.

14. Otang-mbeng $W$, Sagbo IJ. Anti-Tyrosinase Activities of Scabiosa columbaria L. Processes 2020; 8(236).

15. Chaudhari PM, Kawade PV, Funne SM. Cosmeceuticals-A review. Int J Pharm Technol 2011; 3: 774-798.

16. Kaur G, Jabbar Z, Athar M, Alam MS. Punica granatum (pomegranate) flower extract possesses potent antioxidant activity and abrogates Fe-NTA induced hepatotoxicity in mice. Food Chem Toxicol 2006; 44. 984-993.

17. Guo D, Xu L, Cao X, Guo Y, Ye Y, Chan CO, Mok DK, Yu Z, Chen S. Anti-inflammatory activities and mechanisms of action of the petroleum ether fraction of Rosa multiflora thunb. Hips. J Ethnopharmacol 2011; 138: 717-22.

18. Paoletti T, Fallarini S, Gugliesi F, Minassi A, Appendino G, Lombardi G. Anti-inflammatory and vascular protective properties of 8-prenylapigenin. European $\mathrm{J}$ of Pharmacol 2009; 620(1-3): 120-130.

19. Alipour H, Raz A, Zakeri S, Djadid N. Therapeutic applications of collagenase (metalloproteases): $A$ review. Asian J Pac Trop Biomed 2016; 6(11): 975-981.

20. Sharp NE, Aguayo P, Marx DJ, Polak EE, Rash DE, Peter SD, Ostlie DJ, Juang D. Nursing preference of topical silver sulfadiazine versus collagenase ointment for treatment of partial thickness burns in children: survey follow-up of a prospective randomized trial. $J$ Trauma Nurs. 2014; 21(5): 253-257.

21. Lall $N$, Kishore $N$. Are plants used for skin care in south africa fully explored? J Ethnopharmacol 2014; 153: 6184.

Trop J Pharm Res, December 2020; 19(12): 2637 
22. Sonka L. Exploring anti-tyrosinase bioactive compounds from the Cape flora. MSc Dissertation. Department of Biotechnology: University of Western Cape; 2017.

23. Kim CS, Park S, Kim J. The role of glycation in the pathogenesis of aging and its prevention through herbal products and physical exercise. J Exerc Nutr Biochem 2017; 21(3): 055-061.

24. Ramkissoon JS, Mahomoodally MF, Ahmed N, Subratty $A H$. Antioxidant and anti-glycation activities correlates with phenolic composition of tropical medicinal herbs. Asian Pacific J Trop Med 2013; 6(7): 561-569 